\title{
THE ANALYSIS OF HABITUAL BUYING BEHAVIOUR
}

\author{
Viajeng Purnama Putri ${ }^{1}$ \\ ${ }^{1}$ Universitas Muhammadiyah Malang (UMM) Indonesia \\ Email: viajengputri@gmail.com.
}

\begin{abstract}
This study is to test the effect of information and brand liking support for habitual buying behavior. This research sample of 100 respondents, taken based on Purposive Sampling .The data analysis uses PLS software. This path analysis technique will be used in testing the amount of contribution shown by the path coefficient on each path diagram of the causal relationship between variables X1, X2, on $Y$. Information support have a positive and significant effect on habitual buying behaviour Brand liking negative effect on habitual buying behavior and information is able to mediate the effect between brand liking on habitual buying behaviour. information and brand liking had positively and significantly influenced the consumer' responses to habitual buying behavior. The findings of this study contribute to the theory of habitual buying behaviour, namely information and important factors in realizing habitul buying behaviour.
\end{abstract}

Keywords: information, brand liking, habitual buying behaviour

\begin{abstract}
Abstrak
Penelitian ini untuk menguji pengaruh dukungan informasi dan kesukaan merek terhadap perilaku pembelian yang biasa. Sampel penelitian ini sebanyak 100 responden, diambil berdasarkan Purposive Sampling. Analisis data menggunakan software PLS. Teknik analisis jalur ini akan digunakan dalam menguji besarnya kontribusi yang ditunjukkan oleh koefisien jalur pada setiap diagram jalur hubungan kausal antara variabel X1, X2, pada Y. Dukungan informasi berpengaruh positif dan signifikan terhadap kebiasaan membeli perilaku Menyukai merek negatif efek pada kebiasaan membeli dan informasi mampu memediasi pengaruh antara kesukaan merek terhadap perilaku membeli. Informasi dan kesukaan merek berpengaruh positif dan signifikan terhadap respon konsumen terhadap kebiasaan membeli. Temuan penelitian ini berkontribusi pada teori perilaku membeli yang biasa yaitu informasi dan faktorfaktor penting dalam mewujudkan perilaku membeli yang biasa.
\end{abstract}

Kata kunci: informasi, kesukaan merek, kebiasaan membeli

\section{Pendahuluan}

Habitual buying penting untuk perilaku konsumen karena pengulangan dalam pembelian, fitur utama dari kehidupan seharihari. Sekitar $45 \%$ dari perilaku orang diulang hampir setiap hari dan biasanya di konteks yang sama (Quinn \& Wood, 2005; Wood, Quinn, \&
Kashy,2002). Pembelian dan konsumsi juga berulang, konsumen cenderung membeli merek produk yang sama dalam waktu berbelanja yang berbeda (Seetharaman, 2004), pembelianjumlah yang sama di toko ritel tertentu di seluruh kunjungan berulang (Vogel, Evanschitzky, \& Ramaseshan, 2008), dan makan yang serupa 
jenis makanan saat makan sepanjang hari (Khare \& Inman, 2006).

Konsumen mendasarkan keputusan mereka pada informasi yang dikumpulkan dari berbagai sumber dan berbagai bentuk media. Beberapa media memberikan informasi dalam lingkungan yang mencakup komponen audio dan video yang disajikan. Media lain menyediakan informasi dalam lingkungan lain yang hanya terdiri dari teks. Sebagai pemasar mengadopsi augmented reality dan virtual reality untuk pelanggan (Maity et al., 2018).

Dalam konteks pemasaran, mengacu pada sejauh mana nama merek menyampaikan informasi yang bermakna tentang fungsi suatu produk atau atribut (Anandan, 2009), nama merek yang baik (Keller, Aperia, \& Georgson, 2012), menyampaikan keuntungan terutama melalui ingatan dan pengakuan. Kata-kata yang lebih banyak bermakna lebih berkesan. Misalnya, nama merek yang lebih terkait secara integratif dengan produk melalui interaktif lebih diingat daripada nama merek yang tidak terkait dengan atribut atau fungsi produk (Lowrey, Shrum, \& Dubitsky, 2003).

Pembelian ulang bukan alasan seseorang karena habitual buying. Pengulangan konsumen mungkin mencerminkan kelanjutan preferensi untuk produk atau layanan tertentu, keyakinan bahwa itu memenuhi tujuan yang dihargai, atau pengalaman emosi positif. Termotivasi kognisi artinya orang tidak mengetahui motif atau dampaknya (Bargh, 2002). Meski seperti tujuan, sikap, dan emosi tidak diperlukan untuk kinerja kebiasaan, mereka relevan untuk memahami bagaimana orang mengembangkan dan menghentikan kebiasaan. Konsumen terkadang membeli produk berdasarkan kebiasaan, secara otomatis mengulangi perilaku masa lalu dengan sedikit memperhatikan tujuan saat ini dan hasil yang dihargai.

Kebiasaan merupakan bentuk otomatisitas tertentu di mana respons secara misalnya dari lokasi atau tindakan sebelumnya yang secara konsisten dinilai dari kinerja masa lalu. Kebiasaan adalah respons yang masuk akal yang cepat diaktifkan dalam memori, sebuah alternatif dan diingat sepanjang sampai kapanpun. Dalam kehidupan sehari-hari, kecenderungan untuk bertindak berdasarkan kebiasaan diperparah oleh tuntutan sehari-hari, termasuk tekanan waktu.

\section{Tinjauan Pustaka dan Pengembangan hipotesis}

\section{Habitual buying behavior}

Habitual buying behavior adalah keputusan pembelian konsumen yang tingkat keterlibatan konsumennya rendah. Ini berarti bahwa konsumen tidak mencari banyak informasi di antara merek-merek yang tersedia dan mereka tidak menemukan perbedaan signifikan di antara merek-merek tersebut dan membeli produk tanpa keterlibatan konsumen tingkat tinggi.Melakukan pembelian yang berulangulang dengan produk yang sama, menjadi kebiasaan mereka (No \& Sultan, 2019).

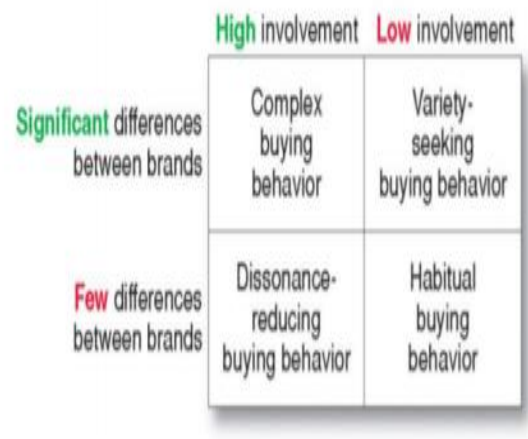

Sumber: Pearson education, Inc. 2012

Gambar 1. Empat Jenis Perilaku Pembelian

Konsumen membeli produk berdasarkan kebiasaan, tidak didasarkan pada loyalitas terhadap merek. Konsumen punya produk berulang kali tidak karena merek produk, tetapi karena mereka akrab dengan produk. Setelah membeli, mereka tidak mengevaluasi kembali mengapa mereka beli produk karena tidak terlibat dengan produk (Kotler, 2009). Perilaku pembelian terakhir disebut perilaku pembelian 
kebiasaan. Ini mengacu pada pembelian barang atau jasa sehari-hari. Pelanggan tidak terlalu terlibat dalam proses dan tidak benar-benar memperhatikan perbedaan antara merek. Memang, pelanggan biasanya tidak terlalu terlibat dalam proses pembelian dan tidak hatihati membandingkan merek yang berbeda. Namun, jika tidak memuaskan, mereka dapat dengan mudah beralih merek. Menurut Kelman, keputusan pembelian pelanggan dapat dipengaruhi oleh tiga mode pengaruh sosial yang berbeda: Yang pertama adalah identifikasi. Itu terjadi ketika seseorang menerima untuk dipengaruhi oleh seseorang karena statusnya wawasan kelompok. Misalnya, ketika seseorang ingin berintegrasi ke dalam sekelompok orang, ia menerima argumen pemimpin tanpa syarat untuk dikaitkan dengannya.

\section{Information}

Model yang melacak proses mengubah kebiasaan lama menjadi yang baru pada awalnya disajikan dalam tujuh langkah (Biel,1997). Garis besar model ini dapat dijelaskan dalam tiga fase. Faktor umum seperti nilai lingkungan dan rasa tanggung jawab pribadi untuk berkontribusi kerusakan lingkungan berpengaruh pada fase awal transisi. Kesadaran lingkungan ini paralel dengan sikap umum yang positif terhadap perilaku ekologis dan dorongan untuk memperhatikan perilaku seseorang saat ini. Pada konteks ini, sikap umum menyatakan suatu evaluasi, positif atau negatif, dari membeli lebih banyak produk ramah lingkungan. Sumber informasi yang sebelumnya disandikan dalam memori dan informasi saat ini dapat bervariasi. Misalnya, konsumen yang melakukan pembelian online cenderung mencari informasi dari situs web di layar komputer atau aplikasi handphone ( Chou, Shen,Chiu, \& Chou, 2016 ).

Sikap umum dapat didukung oleh kepercayaan seperti " produk ekologis lebih baik untuk kesehatan Anda atau produk ekologis kurang berbahaya bagi alam. 'Dalam fase kedua orang-orang mengambilnya perilaku baru menjadi pertimbangan dan memeriksa berbagai cara untuk lakukan perilaku baru ini.
Pertimbangan seperti itu memengaruhi spesifik sikap dan keyakinan. Keyakinan khusus adalah keyakinan tentang kinerja perilaku yang berkaitan dengan objek. Misalnya, keyakinan tertentu tentang membeli daging organik mungkin termasuk keyakinan bahwa Anda mungkin harus membayar lebih untuk organik daripada untuk daging " biasa 'atau percaya bahwa mungkin lebih sulit untuk menemukan daging organik di toko. Dengan demikian, keyakinan khusus di sini diasumsikan mempengaruhi kecenderungan untuk mencoba atau membeli produk tertentu. Setelah perilaku baru diuji itu juga diasumsikan dievaluasi, yang merupakan fase ketiga. Sejak banyak nilai dapat mempengaruhi evaluasi ini, itu dianggap darikepentingan khusus yang dipandu oleh nilainilai lingkungan lebih lanjut perilaku pembelian. Sejalan dengan model, itu juga diasumsikan bahwa jenis informasi yang berbeda lebih efektif di masing - masing tiga fase.

\section{Brand Liking}

Merek sering dianggap sebagai landasan pemasaran. Merek mengubah produk generik menjadi entitas yang ingin dibeli oleh konsumen dan untuk itu mereka akan membayar untuk mendapatkannya (Aaker 1991). Hampir ada kesepakatan universal dalam literatur pemasaran yang berlaku merek produk melibatkan lebih dari sekadar memberi nama produk generik. Seperti yang ditunjukkan oleh definisi Asosiasi Pemasaran Amerika tentang branding, branding mencakup warna, desain, atau simbol yang khusus terkait dengan satu produk. Branding adalah interaksi yang kompleks di antara keduanya atribut fisik produk dan sikap / keyakinan psikologis dan sosial yang diciptakan dalam benak konsumen sasaran yang membedakansatu produk dari yang lain (Simoes dan Dibb 2001).

Branding produk yang sukses memiliki sejumlah konsekuensi penting untuk perusahaan - mungkin yang paling menonjol di antaranya adalah penciptaan ekuitas merek. Ekuitas merek adalah ukuran ringkasan dari kemampuan merek 
untuk menarik dan mempertahankan pelanggan setia yang dinyatakan dalam bentuk uang. Namun loyalitas merek tidak terjadi secara instan. Hal ini timbul dari merek seiring waktu dan, tidak diragukan lagi, ekspresi nyata dari strategi pemasaran (Ye \& Van Raaij, 2004).

\section{Pengaruh information terhadap habitual buying behaviour}

Beberapa studi telah dilakukan untuk menguji model perubahan habitual buying behaviour. Menurut survei (Biel et al., 2005) faktor-faktor umum lebih dalam efek dari beragam informasi pada kelompok konsumen, yaitu konsumen dengan berbagai tingkat kepatuhan terhadap nilai-nilai lingkungan.

\section{Pengaruh Brand Liking Terhadap Habitual Buying Behaviour}

Menurut De Houwer (2008) telah menyatakan, 'Asumsi inti dalam riset pemasaran adalah bahwa konsumen cenderung membeli merek dan produk yang mereka sukai. Meskipun secara intuitif menarik, kesukaan akan merek adalah area riset pasar yang kurang berkembang. Merjuk pada hal-hal berikut: Brand liking 'berupaya membangun sikap positif konsumen terhadap merek berdasarkan keyakinan bahwa merek itu sesuai dengan pribadi seseorang. Berdasarkan tujuan penelitian dan didukung oleh kajian empiris dari berbagai penelitian terdahulu yang menjadi rujukan, maka dapat dibentuk sebuah kerangka konseptual sebagai berikut:

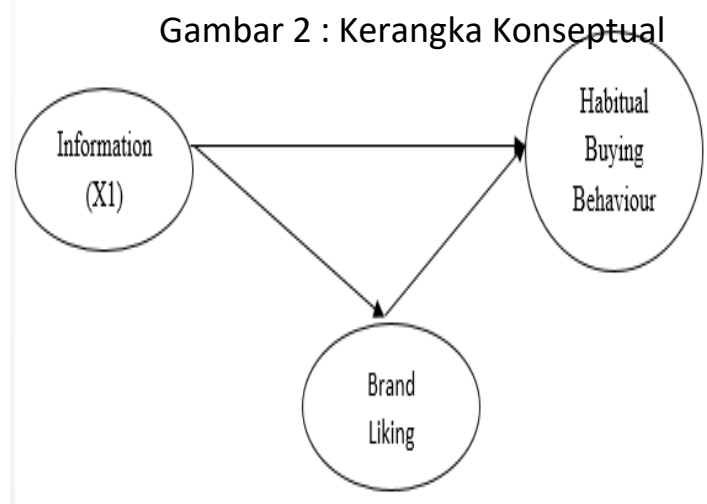

\section{Metode Penelitian}

Populasi dan Teknik pengambilan sampel Populasi adalah wilayah generalisasi yang terdiri atas obyek yang memiliki kualitas dan karakteristik tertentu yang ditetapkan oleh peneliti untuk dipelajari dan kemudian ditarik kesimpulannya (Sugiyono, 2001). Dalam penelitian ini yang menjadi populasinya adalah keseluruhan konsumen yang menjadi pelanggan toko " abc" dengan pembelian minimal 1 (satu) kali dan jumlahnya belum diketahui. Sampel adalah bagian dari populasi yang karakteristiknya hendak diselidiki dan dianggap bisa mewakili keseluruhan populasi, dan jumlahnya lebih sedikit daripada jumlah populasi (Djarwanto, 2000).

Metode pengambilan sampel penelitian adalah probability sampling dimana teknik sampling yang memberikan peluang yang sama bagi anggota populasi untuk dijadikan sampel, jumlah responden yang digunakan adalah 100 . Penelitian ini menggunakan tiga variabel, diantaranya adalah: Informasi (X1), brand liking (X2), dan habitual buying behavior (Y). Penelitian ini menggunakan pemodelan jalur PLS (atau pemodelan persamaan struktural berbasis komponen) memungkinkan untuk memperkirakan model hierarkis (Chin, 2010; MacKenzieet al., 2005, Wetzels et al., 2009). Cocok untuk penelitian kami karena bisa memberikan yang lebih akurat estimasi efek mediasi (Chin et al., 2003, Helm, Eggert, \& Garnefeld, 2010; Henseler \& Fassott, 2010).

\section{Hasil Dan Pembahasan}

Hasil dari analisis data menjelaskan pengaruh antara informasi, brand liking terhadap habitual buying behavior secara langsung maupun tidak langsung melalui mediasi yang ditunjukkan pada gambar 2 . 


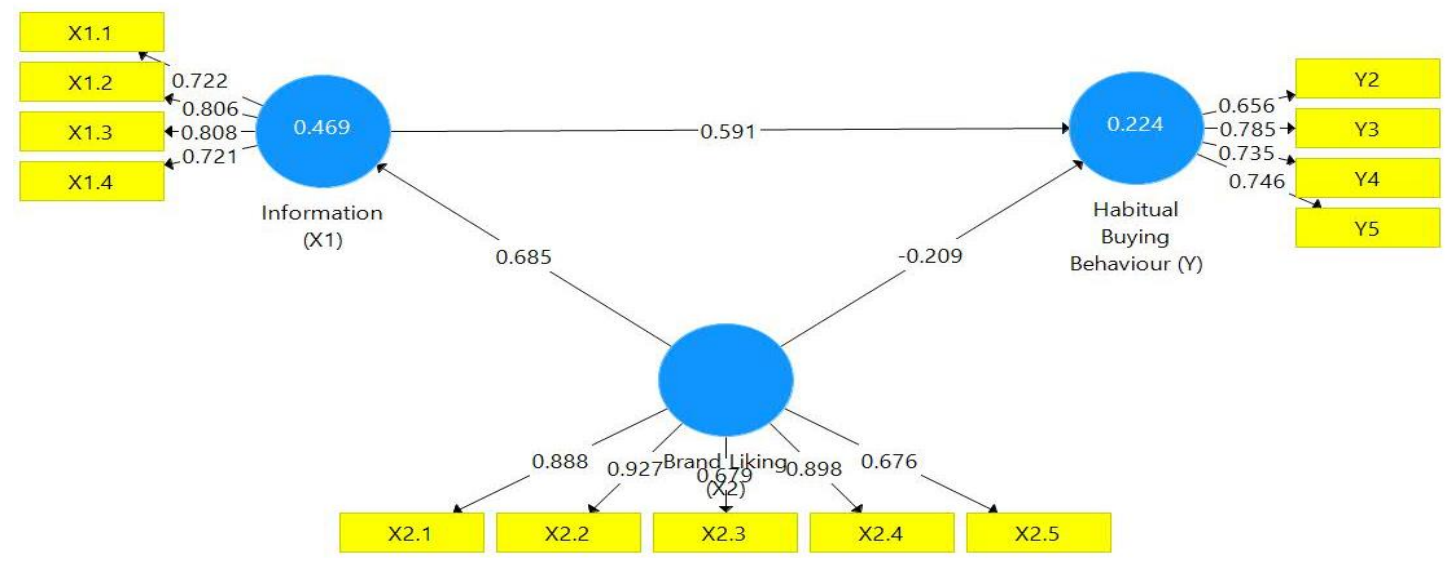

Gambar 2. Hasil Analisis Data

Berikut hasil uji statistik pengaruh langsung disajikan pada tabel 1 berikut:

Tabel 1. Hasil analisis pengaruh langsung

\begin{tabular}{cccccc}
\hline & & \multicolumn{2}{c}{ Estimate } & \\
\cline { 3 - 4 } Hipotesis & Hubungan Variabel & $\begin{array}{c}\text { Path } \\
\text { Coefficien } \\
\text { t }\end{array}$ & $\begin{array}{c}\mathbf{t}- \\
\text { statistic }\end{array}$ & $\begin{array}{c}\text { p- } \\
\text { value }\end{array}$ & Keterangan \\
\hline H1 & Information (X1) & 0.591 & 5.708 & 0.000 & Accepted \\
& HBB (Y) & & & & \\
H2 & BL (X2) -> HBB (Y) & -0.209 & 1.811 & 0.071 & Rejected \\
H3 & BL (X2) -> & 0.685 & 13.531 & 0.000 & Accepted \\
& Information (X1) & & & & \\
\hline
\end{tabular}

Source: Processed primary data, 2020

Hasil analisis pengaruh langsung yang disajikan pada Gambar 1 dan Tabel 1, pengaruh information (X1) pada Habitual buying behaviour(Y) positif pada nilai koefisien 0,591 dan tingkat signifikan 0,000. Karena t-statistik $>1,96$ dan $\mathrm{p}$-value $<0,05$, maka pengaruhnya signifikan. Dengan demikian, hipotesis 1 diterima. Pengaruh Brand liking (X2) pada habitual buying behavior (Y) tidak signifikan pada nilai koefisien $-0,249$ dan t-statistik 1,811 Karena t-statistik $<1,96$ dan p-value $>0,05$, maka tidak berpengaruh signifikan. Dengan demikian, hipotesis 2 ditolak, Secara umum, konsumen menunjukkan keterlibatan yang rendah dengan mayoritas produk yang murah dan sering dibeli.
Mengambil gula sebagai contoh, sedikit konsumen yang sangat terlibat dalam kategori produk ini; mereka hanya pergi ke toko dan membeli gula, terlepas dari mereknya. Jika mereka berulang kali membeli merek yang sama, itu hanyalah hasil dari perilaku kebiasaan daripada loyalitas merek yang kuat (Munthiu, 2009).

Pengaruh Brand liking (X2) pada Habitual buying behaviour (Y) signifikan pada nilai koefisien 0,685 dan t-statistik 13,531 Karena tstatistik> 1,96 dan p-nilai <0,05, maka berpengaruh signifikan. Dengan demikian, hipotesis 3 diterima. 
Tabel 2. Hasil analisis pengaruh tidak langsung

\begin{tabular}{cccccccc}
\hline Hypotheses & $\mathbf{A}$ & $\mathbf{B}$ & $\mathbf{S E}_{\mathbf{A}}$ & $\mathbf{S E}_{\mathbf{B}}$ & t-stat. & Sign. & Information \\
\hline $\mathrm{H} 4$ & 0.685 & 0.591 & 0.051 & 0.104 & 5.233 & 0.000 & Significant
\end{tabular}

Source: Processed primary data, 2020

Information memediasi brand liking terhadap habitual buying behaviour. Hasil analisis diperoleh nilai 5.233> 1,96 dan signifikan $0,00<0,05$. Hasil analisis mengungkapkan bahwa pengaruh variabel brand liking pada information dan pengaruh information pada habitual buying behaviour memiliki hasil yang signifikan sedangkan efek langsung brand liking pada habitual buying behaviour tidak signifikan. Sehingga, variabel information dalam penelitian ini adalah variabel mediasi sempurna (mediasi lengkap). Dengan demikian, Hipotesis 4 diterima.

\section{SIMPULAN}

Berdasarkan analisis pengaruh informasi dan brand liking terhadap habitual buying behaviour kesimpulan yang bisa diambil sebagai berikut: informasi mampu mempengaruhi habitual buying behaviour. Brand liking tidak dapat mempengaruhi habitual buying behavior secara langsung. Informasi juga memediasi hubungan antara brand liking dan habitual buying behaviour. Temuan penelitian ini menunjukkan bahwa brand liking tidak mampu mempengaruhi secara langsung terhadap habitual buying behavior, brand liking akan berpengaruh terhadap habitual buying behavior ketika dimediasi oleh information, perlu dimulai dengan menyiapkan informasi untuk kepentingan perusahaan, di mana dukungan informasi tersebut mempengaruhi pembentukan habit konsumen, yang kemudian menjadi kekuatan perusahaan dalam membuat perubahan. Perusahaan selalu mempertahankan kesetiaan konsumen terhadap merek perusahaan. Dalam hal ini, memberikan informasi adalah faktor terpenting yang harus dikedepankan dalam membangun, kepercayaan, dan kepercayaan konsumen terhadap perusahaan yang pada dasarnya mendorong konsuemen untuk selalu membeli produk di perusahaan tersebut.

\section{DAFTAR PUSTAKA}

Aaker, D. A. 1991. Managing Brand Equity. New York: The Free Press.

Anandan, C. (2009). Product management (2nd Ed.). New Delhi: Tata McGrawHill.

Batra, R., Ahuvia, A., \& Bagozzi, R. P. (2012). Brand love. Journal of Marketing, 76(2), 1-16.

Biel, A., Dahlstrand, U., \& Grankvist, G. (2005). Habitual and value-guided purchase behavior. Ambio, 34(4-5), 360-365. ttps://doi.org/10.1579/00447447-34.4.360

Cătoiu I. \& Teodorescu N. 2004. Comportamentul consumatorului (Consumer behaviour), ediţia a II-a, revăzută şi adăugită, Editura Uranus, Bucureşti. 
Chou,S.-Y.,Shen,G.C.,Chiu,H.-C.,\&Chou,Y.T.(2016).Multichannelserviceproviders' strategy: Understanding customers' switching and free-riding behavior. Journal of Business Research, 69(6), 2226-2232.

Dahlstrand, U. and Biel, A. 1997. Proenvironmental habits: propensity levels in behavioral change. J. Appl. Social Psychol. 27, 588-601.

Goldstein. Harvey, Age, Period and Cohort Effects-A Confounded Confusion, Bull. Applied Stat. 6 (1979): 19-24.

Grankvist, G. and Biel, A. 2001. The importance of beliefs and purchase criteria in the choice of eco-labeled food products. J. Environ. Psychol. 21, 405410

Hansen, Flemming. Corzsumer Choice Behavior. Free Press, New York, 1972.

Keller, K. L., Apéria, T., \& Georgson, M. (2012). Strategic brand management: A European perspective, 2nd ed. Essex: Prentice Hall.

Kotler P. \& Keller, K. 2006. Marketing Management, Pearson Prentice Hall, New Jersey.

Kotler P. \& Armstrong G. 2008. Principles of Marketing, Pearson Prentice Hall, New Jersey.

Lowrey, T. M., Shrum, L. J., \& Dubitsky, T. M. (2003). The relation between brandname linguistic characteristics and brandname memory. Journal of Advertising, 32(3), 7-17.

Low, G., and C. Lamb. 2000. 'The Measurement and Dimensionality of Brand Associations.' Journal of Product and Brand Management 9 (6):350-68

Biel, A., Dahlstrand, U., \& Grankvist, G. (2005). Habitual and value-guided purchase behavior. Ambio, 34(4-5), 360365. https://doi.org/10.1579/0044-744734.4.360

Maity, M., Dass, M., \& Kumar, P. (2018). The impact of media richness on consumer information search and choice. Journal of Business Research, 87(January), 36-45. https://doi.org/10.1016/j.jbusres.2018.02. 003

Munthiu, M.-C. (2009). The buying decision process and types of buying decision behaviour. Sibiu Alma Mater University Journals, 2(4), 27-33. https://pdfs.semanticscholar.org/9e43/3b 95d3416489b5c70d0fac8b1d9f6dea7e8a. pdf No, I. V., \& Sultan, K. (2019). An Assessment of Commercial Advertisement' s Effects on Consumer Buying Behaviour: A Case Study of Internet Companies In Erbil KRI. International Journal of Research in Business and Social Science, 8(1), 90102.

https://doi.org/10.1080/13527260410001 693794

Simoes, C., and S. Dibb. 2001. 'Rethinking the Brand Concept: New Brand Orientation.' Corporate Communications 6 (4): $217-$ 24.

Steenkamp, J.-E., R. Batra, and D. Alden. 2003. 'How Perceived Brand Globalness Creates Brand Value.' Journal of International Business Studies 34 (1): $53-$ 65.

von Borgstede, C. and Biel, A. 2002. Proenvironmental behavior: situational barriers and concern for the good at stake. Goteborg Psychological Reports, 32, No. 1. Goteborg University, Department of Psychology. 10 pp.

Wood, W., \& Neal, D. T. (2007). A new look at habits and the habit-goal interface. Psychological Review, 114, 842-862.

Wood, W., Quinn, J., \& Kashy, D. (2002). Habits in everyday life: Thought, emotion, and action. Journal of Personality and Social Psychology, 83,12811297.

$\mathrm{Xu}$, J. A., \& Wyer, R. S. (2008). The effect of mindsets on consumer decision strategies. Journal of Consumer Research, 35, 556-566.

Ye, G., \& Van Raaij, W. F. (2004). Brand equity: Extending brand awareness and liking with signal detection theory. 
Journal of Marketing Communications, 10(2), 95-114.

Yin, H. Y., \& Knowlton, B. J. (2006). The role of the basal ganglia in habitformation. Nature Reviews Neuroscience, 7, 464-476.

Yoon, C., Cole, C. A., \& Lee, M. P. (2009). Consumer decision making and aging: Current knowledge and future directions. Journal of Consumer Psychology, $19,2-16$ 